1 Biologische Bundesanstalt für Land- und

Forstwirtschaft, Institut für Pflanzenschutz im

Obstbau, D-69221

Dossenheim, Germany

2 Horticulture Research International, East Malling, Kent ME19 6BJ, UK

3 Biologische Bundesanstalt für Land- und

Forstwirtschaft, Institut für Pflanzenvirologie, Mikrobiologie und biologische Sicherheit, D-38104 Braunschweig, Germany

4 Deutsches Krebsforschungszentrum, Abteilung molekulare Biologie der Mitose, D-69120 Heidelberg, Germany

\section{Isolation of the gene encoding an immunodominant membrane protein of the apple proliferation phytoplasma, and expression and characterization of the gene product}

\author{
Michael Berg, ${ }^{1}$ David L. Davies, ${ }^{2}$ Michael F. Clark, ${ }^{2}$ H. Joseph Vetten, ${ }^{3}$ \\ Gernot Maier, ${ }^{4}$ Carmine Marcone ${ }^{1}$ and Erich Seemüller ${ }^{1}$
}

Author for correspondence: Erich Seemüller. Tel: +496221868 0550. Fax: +4962218680515. e-mail: erich.seemueller@urz.uni-heidelberg.de

An immunodominant membrane protein (IMP) of the apple proliferation (AP) phytoplasma was detected in preparations from AP-diseased periwinkle plants using monoclonal and polyclonal antibodies to the AP agent. Following isolation from Western blots and partial sequencing, degenerate oligonucleotides derived from the IMP sequence were used as probes to identify a DNA fragment containing the ORF encoding the IMP. Complete sequencing and subsequent analysis of the cloned DNA fragment revealed the presence of two ORFs, predicted to encode proteins with molecular masses of $25 \mathrm{kDa}(\mathrm{P}-318 \mathrm{~A})$ and $19 \mathrm{kDa}$ (P-318B). Whilst database searches failed to assign a possible function to P-318A, analysis of P-318B predicted an amphiphilic membrane protein with a positively charged $\mathrm{N}$-terminal portion, followed by a hydrophobic segment forming an $\alpha$-helix, and a hydrophilic C-terminal part located outside of the cell. The amphiphilic nature of P-318B was confirmed by its solubility in Triton X-114. The gene encoding P-318B was expressed in Escherichia coli and the resulting protein was used to immunize rabbits. The antiserum obtained reacted specifically with P-318B. The same protein was also detected by an antiserum raised against antigen preparations from APdiseased plants. The P-318B antiserum did not react with antigen preparations from plants infected with the closely related pear decline phytoplasma. However, in Southern hybridization studies, the gene encoding the IMP hybridized to genomic fragments of the pear decline and European stone fruit yellows phytoplasmas. It also showed significant sequence similarity to a gene encoding an antigenic membrane protein of the sweet potato witches' broom phytoplasma, but not to a gene encoding a major immunogenic membrane protein of an aster yellows group phytoplasma. Since it appears that most phytoplasmas possess a major immunogenic membrane protein which may have a function in pathogenesis, this work may be a basis for further studies on fundamental aspects of host-pathogen interactions. It also describes a new approach to obtain suitable immunogens to produce specific antibodies for detection and characterization of the non-culturable phytoplasmas.

Keywords: phytoplasma, apple proliferation, gene, immunogenic membrane protein, antiserum

Abbreviations: AP, apple proliferation; AY, aster yellows; ESFY, European stone fruit yellows; IMP, immunodominant membrane protein; pAb, polyclonal antibody; PD, pear decline; SPWB, sweet potato witches' broom.

The EMBL database accession number for the sequence determined in this work is AJ011678. 


\section{INTRODUCTION}

Phytoplasmas are wall-less, non-helical prokaryotes of the class Mollicutes (trivial name mycoplasmas). They are associated with several hundred plant diseases, of which many are of considerable economic importance (McCoy et al., 1989; Seemüller et al., 1998). Because phytoplasmas resist all attempts at culture under axenic conditions, our knowledge about their physiology, biochemistry and molecular biology is limited. It is largely unknown how phytoplasmas interact with their plant host. In contrast, for several culturable mycoplasmas infecting humans and animals it is wellestablished that adherence to host membranes is an important factor in pathogenesis. This adherence is mediated by surface-exposed protein adhesins, which in some species are organized in specialized attachment structures (tips) (Kahane \& Horowitz, 1993). Adhesins such as P1 of Mycoplasma pneumoniae and $\mathrm{MgPa}$ of Mycoplasma genitalium are known to be major immunogens (Krause \& Taylor-Robinson, 1992). Mycoplasma surface proteins may also show antigenic variation. It is supposed that this phenomenon plays an important role in pathogenesis, enabling the invading pathogens to escape the immune response of vertebrate hosts (Wise et al., 1992).

Western blot experiments have shown that in most phytoplasmas studied a single immunodominant protein forms the major portion of semi-purified cell-membrane preparations (Barbara et al., 1998). Studies by immunosorbent electron microscopy suggested that such a protein of the 'chlorante' strain of the aster yellows (AY) phytoplasma group is exposed outside the bacterial cell membrane (Milne et al., 1995). This polypeptide has been partially characterized and its gene has been cloned and sequenced (Barbara et al., 1998). Another gene encoding an antigenic membrane protein of sweet potato witches' broom (SPWB) phytoplasma has also been cloned and analysed (Yu et al., 1998). Although the function of these and other phytoplasma membrane proteins is unknown, they may play an important role in pathogen-host interactions. Thus, in order to contribute to a better understanding of phytoplasma pathology at the molecular level, the objective of our work was to obtain more information about an immunodominant membrane protein (IMP) of the phytoplasma causing apple proliferation (AP), one of the most economically important phytoplasmoses in Europe. The causal agent of AP forms, together with other temperate fruit-tree pathogens such as the phytoplasmas causing pear decline (PD), European stone fruit yellows (ESFY) and peach yellow leaf roll, a distinct group within the monophyletic phytoplasma clade (Seemüller et al., 1998). Our work consisted of isolating, cloning, sequencing and expressing the gene encoding the IMP and partially characterizing the gene product. The fusion protein obtained was used to produce polyclonal antibodies (pAbs) to IMP for detection and characterization of the AP phytoplasma.

\section{METHODS}

Phytoplasmas. The phytoplasmas used were strain AT of the AP phytoplasma, strain PD1 of the PD phytoplasma, strain GSFY of the ESFY phytoplasma, strain STOL of the stolbur phytoplasma and strain AAY of the AY phytoplasma group. More information on origin and taxonomic positions of these phytoplasmas is given elsewhere (Seemüller et al., 1998). All strains were maintained in Catharanthus roseus (periwinkle) in an insect-proof greenhouse. Strain AT was also maintained in Nicotiana tabacum cv. Samsun (tobacco) and Nicotiana occidentalis.

Detection and micro-sequencing of IMP. Antiserum to AP phytoplasma, propagated in C. rosens, was raised in a rabbit (Scorpio) using a protocol similar to that described by Clark $e t$ al. (1989). mAbs to AP phytoplasma were obtained using a mouse tolerization procedure (M. F. Clark \& D. L. Davies, unpublished results). To prepare the IMP of the AP phytoplasma, a clarified extract of stems, petioles and midribs from AP-infected periwinkle plants was enriched for phytoplasmas by centrifugation at $60000 \mathrm{~g}$ for $30 \mathrm{~min}$ (Clark et al., 1989). Following resuspension of the pellet in the extraction buffer, approximately $50 \mu \mathrm{g}$ of EMA $167 \mathrm{mAb}$ was added. After incubation, the immune complex was collected by centrifugation, resuspended in GM buffer $(0 \cdot 3 \mathrm{M}$ glycine $/ \mathrm{NaOH}$, $20 \mathrm{mM} \mathrm{MgCl}_{2}, \mathrm{pH} \mathrm{8.0)}$ and incubated with a suspension of BioMag magnetic beads coated with goat anti-mouse antibodies according to the protocol of the supplier (PerSeptive Diagnostics). The mixture was further incubated for $3 \mathrm{~h}$ at $40^{\circ} \mathrm{C}$ with gentle shaking before collecting the beads using a magnetic separator. The beads were washed twice with PBS (137 mM NaCl, $2.7 \mathrm{mM} \mathrm{KCl,} 4.3 \mathrm{mM} \mathrm{Na} \mathrm{NPO}_{4} .7 \mathrm{H}_{2} \mathrm{O}$, $1.4 \mathrm{mM} \mathrm{KH}_{2} \mathrm{PO}_{4}$ ), resuspended in $1.0 \mathrm{ml}$ PAGE sample buffer and the whole mixture subjected to SDS-PAGE (Laemmli, 1970). The IMP band was excised from the gel, cut into small fragments (approx. $4 \mathrm{~mm}$ wide) and resubjected to SDS-PAGE for further purification, loading three to four fragments per well. Following electrophoresis, the IMP protein was electroblotted on to a PVDF membrane using a carbonate transfer buffer $\left[10 \mathrm{mM} \mathrm{NaHCO}, 2 \mathrm{mM} \mathrm{Na} \mathrm{NaO}_{3}, 20 \%(\mathrm{v} / \mathrm{v})\right.$ methanol].

For sequence analysis of the $\mathrm{N}$ terminus of IMP blotted to PVDF membrane, the resolved bands were visualized by staining with Ponceau red. Membrane fragments (about $1 \mathrm{~mm}^{2}$ ) containing the IMP were excised and transferred into the reaction chamber of an $\mathrm{ABI} 470 \mathrm{~A}$ automated gas phase sequencer (Applied Biosystems) and subjected to Edman sequence analysis according to the manufacturer's protocols.

DNA isolation. Stems and leaves of $N$. occidentalis infected with strain AT were lyophilized and ground to a fine powder. Phytoplasma DNA was isolated and purified using a cetyltrimethylammonium bromide (CTAB) procedure followed by $\mathrm{CsCl} /$ hisbenzimide density-gradient centrifugation (Kollar \& Seemüller, 1989). DNA from periwinklemaintained strains was obtained using a phytoplasma enrichment procedure as described by Ahrens \& Seemüller (1992).

Isolating, cloning and sequencing of the IMP gene. For detection of the IMP gene by Southern blot analysis, $\mathrm{CsCl} /$ bisbenzimide-enriched DNA from periwinkle plants infected with strain AT was digested separately with restriction enzymes HindIII and EcoRI. Following electrophoresis in $1 \%$ agarose gel, DNA was transferred to nylon membrane (Hybond-N+, Amersham). Southern blot hybridization was performed using degenerate oligonucleotides designed on the 
basis of the amino acid sequence of the $\mathrm{N}$ terminus of the IMP of strain AT, assuming universal codon usage. The oligonucleotide probe was labelled with $\gamma_{-}{ }^{32} \mathrm{P}-\mathrm{dATP}$ using T4 phosphokinase (Sambrook et al., 1989).

For cloning of the IMP gene, about $40 \mu \mathrm{g}$ EcoRI-digested $\mathrm{CsCl} /$ bisbenzimide-enriched phytoplasma DNA was electrophoresed as described above and fragments of the size corresponding to the fragment containing the IMP gene sequence were excised from the gel. DNA was recovered using the Jetsorb method (Genomed). DNA fragments were ligated into plasmid vector pBluescript SK (Stratagene) and the plasmid was used to transform Escherichia coli strain XL-1 Blue MRF'. Recombinant clones were screened for the presence of the IMP gene sequence by Southern blot analysis of plasmid preparations (Sambrook et al., 1989). One cloned fragment containing the desired gene was fully sequenced using a dideoxy termination protocol, FITC and $\mathrm{Cy} 5$ fluorophore-labelled primers, and the ARAKIS automated DNA sequencer at the sequencing facility of LION Bioscience. Nucleic acid and protein sequences were compared with the EMBL databases EPRO and SWALL using programs FASTA and BLAST. Predict Protein Server of EMBL was used for protein analysis. The accession number of the sequence encoding the immunogenic membrane protein and an adjacent protein of SPWB phytoplasma is U15224 (Yu et al., 1998).

Heterologous expression of the IMP-encoding gene. ORFs present in the sequenced AP phytoplasma DNA fragment were separately amplified by PCR using standard procedures (Lorenz et al., 1995). The primers used were complementary to the $5^{\prime}$ and $3^{\prime}$ termini of the ORFs or derived from a flanking region. For site-directed cloning, the primers were extended on both sides with the sequence of either a Bam HI or HindIII recognition site according to the protocol of the supplier of the expression system (Qiagen). Amplification products were resolved in an agarose gel $(1 \%)$, recovered from the gel using the Jetsorb procedure (Genomed) and ligated into plasmid vector pBluescript (Stratagene) following a procedure described by Holton \& Graham (1990). Transformation of E. coli strain XL-1 Blue MRF' was performed as described above. Recombinant plasmids were isolated and the insert excised by BamHI and HindIII digestion. After gel electrophoresis, fragments containing the desired genes were isolated and separately cloned in E. coli strain M15 using the expression vector pQE30 (Qiagen). Expression of the cloned genes was induced following the protocol of the supplier. Expression and solubility of the proteins obtained from small-scale cultures were examined by discontinuous SDS-PAGE (Laemmli, 1970). Expressed proteins were purified from large-scale cultures using a Ni-NTA resin column following the instructions of the supplier (Qiagen). Protein elution was monitored by absorption at $280 \mathrm{~nm}$.

Production of antisera to expression products and serological tests. Antisera to expression products were raised in two rabbits which received four intramuscular injections at intervals of 1-2 weeks over a period of 4-5 weeks using a $1: 1$ mixture of purified expression product and either Freund's complete (first injection) or incomplete (subsequent injections) adjuvant. Each injection contained about $100 \mu \mathrm{g}$ protein. Animals were bled four to five times from the marginal ear vein at intervals of $14 \mathrm{~d}$ beginning $5-6$ weeks after the first injection.

For Western blot analysis, phloem tissue from healthy and APdiseased tobacco and leaf midribs from healthy periwinkles and periwinkles infected with AP or PD phytoplasma were extracted using the phytoplasma enrichment procedure de- scribed by Ahrens \& Seemüller (1992). To identify amphiphilic membrane-bound proteins, the Triton-X114 phase fractionation method was used (Bordier, 1981). Proteins partitioned in the Triton-X114 phase, present in the aqueous phase, and insoluble proteins were precipitated and washed with cold acetone. Proteins of each fraction and purified expression products were examined by discontinuous SDS-PAGE. Proteins were transferred to nitrocellulose membranes (Hybond-C; Amersham) using a semi-dry blotting chamber (Bio-Rad) following the protocol of the supplier. Immunological detection of blotted proteins was performed according to Sambrook et al. (1989).

An indirect $\mathrm{F}\left(\mathrm{ab}^{\prime}\right)_{2}$-based ELISA procedure was used to detect phytoplasma antigens in partially purified preparations from midveins of AP-affected periwinkle plants, using a method described by Clark et al. (1989). Double antibody sandwich (DAS) ELISA was performed according to a protocol recommended by Loewe Phytodiagnostica (Sauerlach, Germany). In brief, microplates were coated with anti-IMP polyclonal IgG to capture antigens from fresh plant extracts, and alkalinephosphatase-conjugated anti-IMP polyclonal $\operatorname{IgG}$ was used for antigen detection. As substrate, $p$-nitrophenyl phosphate was used. Coating IgG was diluted $1: 1000$ and IgG conjugated to alkaline phosphatase was diluted $1: 2000$.

Sequence similarity of the IMP gene. DNA from phytoplasma-infected periwinkle plants was cleaved with EcoRI and, following gel electrophoresis, transferred to nylon membrane (Hybond-N+; Amersham). Southern hybridization was performed as described by Hoheisel et al. (1991) using PCR-amplified protein genes as probes. PCR amplification of protein gene sequences was carried out as described by Lorenz et al. (1995).

\section{RESULTS}

\section{Isolation and micro-sequencing of IMP}

Using mAb EMA167 to strain AT, Western blot analysis of antigen preparations from AT-infected periwinkle plants gave a strong reaction with a single protein, about $20 \mathrm{kDa}$ in size. No such band was observed with preparations from healthy plants. Sequence analysis of the N-terminal region of the protein reacting with the antibodies provided the amino acid sequence MEANQQTPILIGVGSVVG. From this sequence, degenerate oligonucleotides fMPAT $\left(5^{\prime}-\mathrm{GGT} / \mathrm{A}, \mathrm{C}\right.$ GTT/A GGT/A,C TCT/A GTT/A GTT/A GG-3') and $\mathrm{rMPAT}\left(5^{\prime}-\mathrm{A} / \mathrm{TGT}\right.$ TTG TTG G/ATT T/AGC C/TTC CAT-3') were designed.

\section{Detection and cloning of the IMP gene}

Using a mixture of oligonucleotides $\mathrm{fMPAT}$ and $\mathrm{rMPAT}$ as probe, a single DNA fragment was detected by Southern blot hybridization in both HindIII- and EcoRIdigested DNA, enriched by $\mathrm{CsCl}$ /bisbenzimide densitygradient centrifugation from diseased $N$. occidentalis. The size of the HindIII fragment was approximately $5.0 \mathrm{~kb}$ and that of the EcoRI fragment approximately $1.7 \mathrm{~kb}$ (Fig. 1). Plasmid cloning of EcoRI fragments similar in size to those detected in Southern hybridization yielded three clones which hybridized to the oligonucleotide probe. 


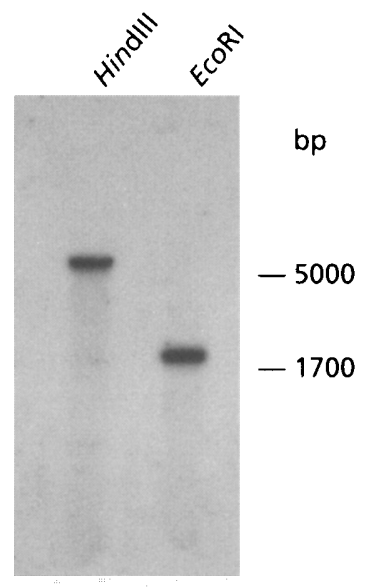

Fig. 1. Detection of the IMP gene by Southern blot hybridization of enriched AP phytoplasmal DNA digested with HindIII and EcoRI. A mixture of two radiolabelled degenerate IMP-derived oligonucleotides was used as probe.

\section{Nucleotide sequence analysis}

The insert of one recombinant plasmid (pAT318) hybridizing with the oligonucleotide probe was fully sequenced. Sequence analysis revealed that the cloned fragment consisted of $1685 \mathrm{bp}$ and contained two ORFs, named AT318A and AT318B. AT318B was 495 bp in length (nt 885-1379) and was predicted to encode a $18.97 \mathrm{kDa}$ peptide (165 amino acid residues), the $\mathrm{N}$ terminus of which differed in only two amino acids from the sequence determined by micro-sequencing (see above). Analysis of the deduced peptide predicted an amphiphilic membrane protein with a pI value of 9.01. It consisted of a positively charged short $\mathrm{N}$-terminal segment followed by a hydrophobic segment composed of 18 amino acids which was predicted to form an $\alpha$ helix, and a hydrophilic C-terminal part (amino acids 33-165). Cleavable signal peptides characteristic for certain integral membrane proteins were not found. The deduced protein showed the highest sequence similarity (27.6\% identity) with an antigenic membrane protein of the SPWB phytoplasma which consists of 172 amino acid residues. The nucleotide sequence identity of these two genes was $54 \%$. There was no significant homology to the nucleotide and amino acid sequences of an immunogenic membrane protein of the 'chlorante' strain of the AY phytoplasma group.

ORF AT318A consisted of 612 bp (nt 120-731) and was located directly upstream of ORF AT318B. It was predicted to encode a $24.5 \mathrm{kDa}$ protein (204 amino acid residues) and had $64 \%$ DNA sequence identity with a $612 \mathrm{bp}$ gene of the SPWB phytoplasma which, as in strain AT, lies directly upstream of the antigenic membrane protein gene. Sequence analysis gave no information about its function. The amino acid sequence identity of the ORF AT318A product and the related

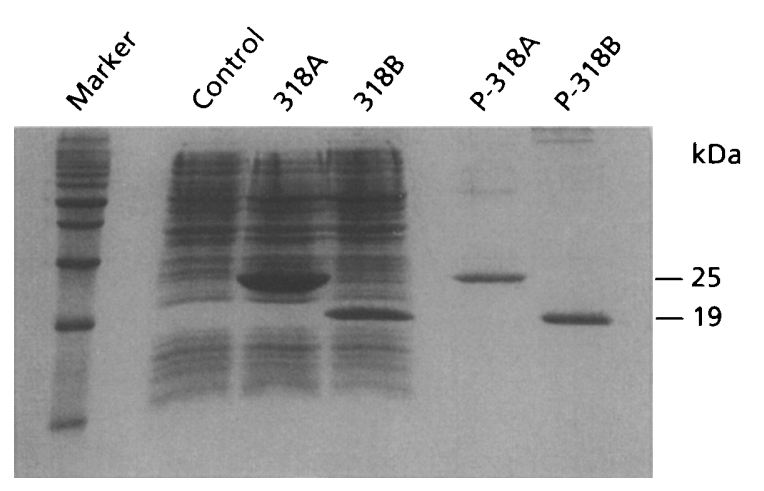

Fig. 2. SDS-PAGE analysis of recombinant $E$. coli expressing ORFs AT318A and AT318B of the AP phytoplasma. Control, clone 318A without IPTG; $318 \mathrm{~A}$ and 318B, clones 318A and $318 \mathrm{~B}$ with IPTG. The two lanes on the right show purified expression products P-318A and P-318B. A $10 \mathrm{kDa}$ ladder (Gibco-BRL) was used as size marker.

protein of the SPWB phytoplasma was $40 \cdot 7 \%$. Both ORFs AT318A and AT318B were preceded by a putative Shine-Dalgarno sequence 5'-AAGGAG-3' (Shine \& Dalgarno, 1974) which was identical to that of $f u s$ and tuf genes of the AP phytoplasma (Berg \& Seemüller, 1999). The coding region of both genes started with the ATG initiation codon and stopped at translation termination codon TAA. Transcription termination structures between the two ORFs were not identified, suggesting that they were cotranscribed.

\section{Expression of proteins}

Based on distal sequences or a sequence of a flanking region $(\mathrm{r} 318 \mathrm{~A})$ of ORFs $\mathrm{AT} 318 \mathrm{~A}$ and $\mathrm{AT} 318 \mathrm{~B}$, primer pairs $\mathrm{f} 318 \mathrm{~A} / \mathrm{r} 318 \mathrm{~A}\left(5^{\prime}\right.$-GGA TCC ATG ATT AAA AAA CTT TAT GAA G-3'/5'-AAG CTT CAA AAA ATC AAA TAA ATA TTG-3') and f318B/r318B (5'-GGA CTT ATG GAA GCA AAT CAA CAA A-3' $/ 5^{\prime}$-AAG CTT TTA TTT CAA ATC TAA AGC AG-3') were designed to separately amplify genes AT318A and AT318B, respectively. Amplification products were cloned and expressed in $E$. coli using expression vector system pQE (Qiagen). SDS-PAGE analysis of proteins from small-scale expression cultures revealed that both genes were expressed. Compared with the uninduced control cultures, the recombinant clone containing gene AT318A expressed an extra $25 \mathrm{kDa}$ protein (P-318A) and the recombinant clone containing gene AT318B expressed an additional protein of approximately $19 \mathrm{kDa}$ (P-318B) (Fig. 2). Each of the expressed proteins reacted with Scorpio antiserum to the AP phytoplasma (not shown).

Preparative scale expression cultures $(500 \mathrm{ml})$ of the two recombinant clones yielded, after purification on $\mathrm{Ni}$ NTA columns, about $4 \mathrm{mg}$ each of P-318A and P-318B. Both proteins were of the expected size when analysed by SDS-PAGE (Fig. 2). 


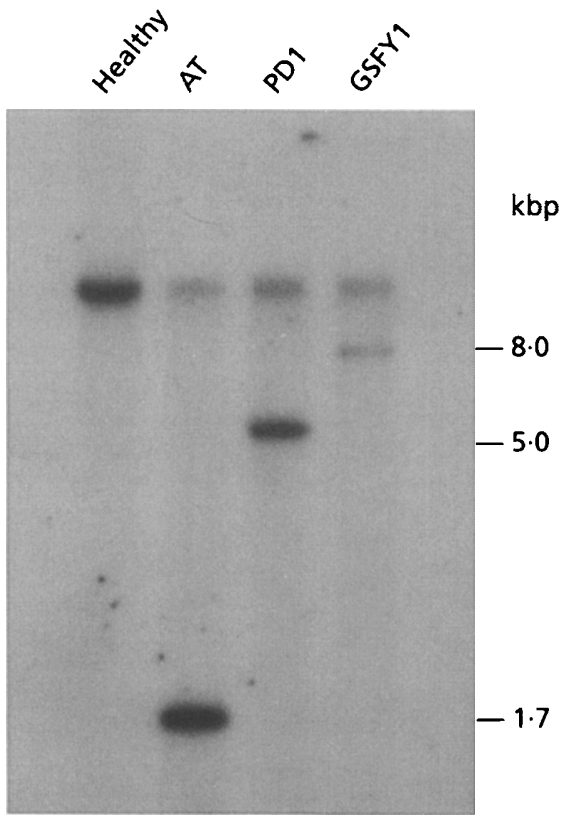

Fig. 3. RFLPs within AP-group phytoplasmas revealed by Southern biot hybridization of DNA from healthy periwinkle plants and from periwinkles infected with AP (AT), PD (PD1) and ESFY (GSFY1) phytoplasmas. Gene AT318B was used as probe. The common upper bands are due to non-specific hybridization.

\section{Similarity of membrane protein genes to other phytoplasma genes}

When Southern blots of EcoRI-digested DNA from C. roseus plants infected with strains AT, PD1 (PD phytoplasma), or GSFY (ESFY phytoplasma) were separately hybridized with genes AT318A and AT318B as probes, both genes hybridized to the same fragment of each strain. However, the size of the fragments was different. Whereas the AP fragment recognized by the probes showed the expected size of $1.7 \mathrm{~kb}$, the hybridizing fragments of strains PD1 and GSFY were approximately $5 \mathrm{~kb}$ and $8 \mathrm{~kb}$, respectively (Fig. 3). Primers f318A/r318A and f318B/r318B did not amplify a product from DNA of strains PD1 and GSFY. In Southern blot analysis, no signals were obtained when EcoRI-restricted DNA from periwinkle plants infected with strains AAY (AY group phytoplasma) or STOL (stolbur phytoplasma) was hybridized with probes AT318A and AT318B (data not shown).

\section{Serological tests}

The antisera to the expression products $\mathrm{P}-318 \mathrm{~A}$ and $\mathrm{P}$ $318 \mathrm{~B}$ gave specific Western blot reactions only with the homologous proteins that had been used as immunogens (Fig. 4). The pAbs to P-318B also showed a strong reaction with the $19 \mathrm{kDa}$ membrane protein of the AP phytoplasma in antigen preparations from AP-infected tobacco and periwinkle plants. This protein was identical in size to that recognized by mAbs and pAbs raised
P-318A

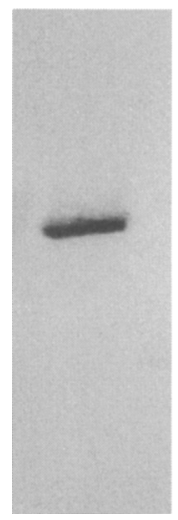

P-318B

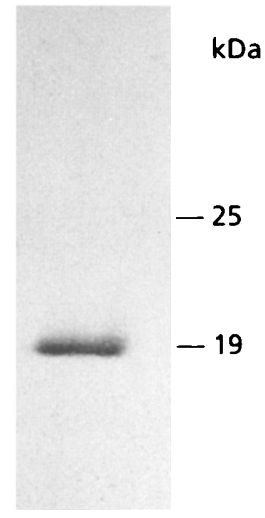

Fig. 4. Western blot analysis of purified expression proteins $P$ $318 \mathrm{~A}$ and $\mathrm{P}-318 \mathrm{~B}$ incubated with the homologous antisera obtained by immunization of rabbits.

to phytoplasma antigens from infected plants (not shown). When antigen preparations from AP-infected plants were partitioned with Triton-X114, the corresponding antigen was detected in the Triton-X114 phase whereas there was no reaction with the aqueous phase or the insoluble protein fraction. This result demonstrated the amphiphilic nature of the IMP and supported the algorithmic predictions. The pAbs to P$318 \mathrm{~B}$ did not react with antigen preparations from PDinfected periwinkle plants and reacted only nonspecifically with extracts from healthy periwinkles (Fig. $5)$. The pAbs to P-318A failed to react specifically with phytoplasma antigens in preparations from AP-infected periwinkle and tobacco plants (not shown).

Specificity of the pAbs to P-318B was also shown in ELISA. Under the test conditions used, $A_{405}$ values of 1.376 and 0.288 were obtained after an incubation of $1 \mathrm{~h}$ at room temperature when phytoplasma-enriched preparations from AP-diseased periwinkle plants were diluted 1000-fold and 10000-fold (fresh weight/ volume), respectively. The corresponding values obtained with preparations from uninfected plants were 0.068 and 0.035 , respectively.

\section{DISCUSSION}

Whereas structure and function of membrane proteins of culturable mycoplasmas have been intensively studied (for a review see Wieslander et al., 1992), little is known about phytoplasma membrane proteins. During the last decade a single major antigenic protein with a molecular mass ranging from 15.7 to $23 \mathrm{kDa}$ was identified in several phytoplasmas (Jiang et al., 1988; Clark et al., 1989; Garnier et.al., 1991; Onuki et al., 1992; Saeed et al., 1992; Erampalli \& Fletcher, 1993; Seddas et al., 1993; Chang et al., 1995). In our study, a similar-sized protein with a molecular mass of about $19 \mathrm{kDa}$ was detected in preparations from AP-infected periwinkle and tobacco plants. Analysis of the deduced protein 


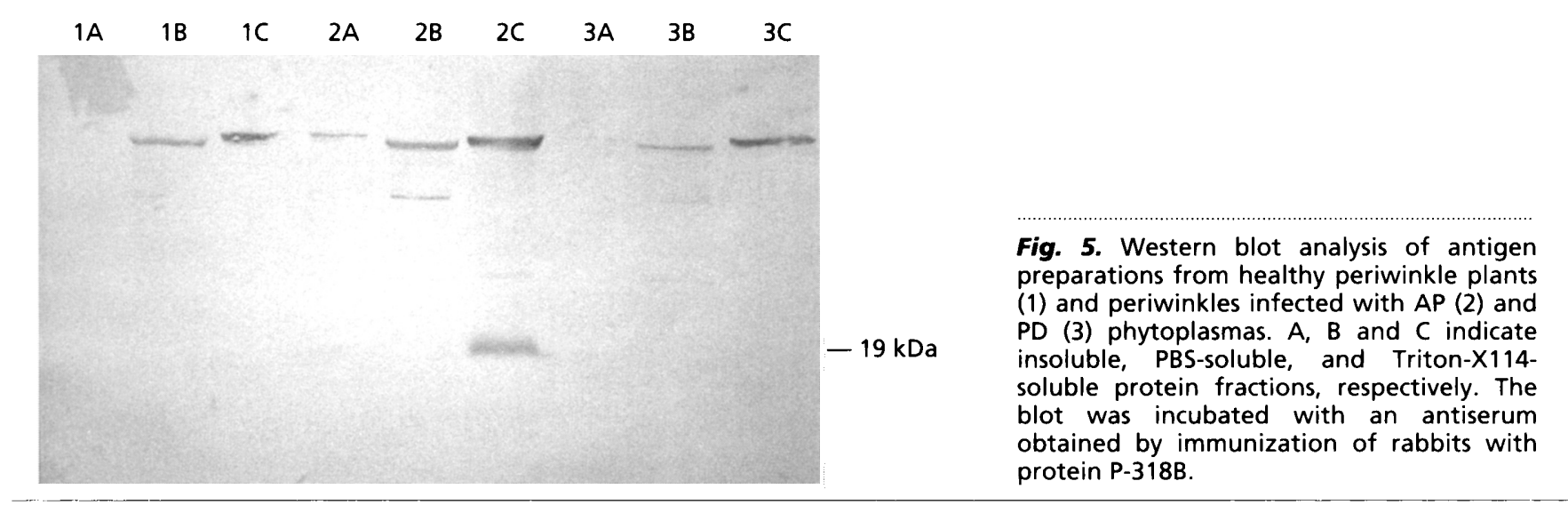

sequence indicated typical features of a class of bitopic integral membrane proteins characterized by a positively charged $\mathrm{N}$-terminal segment exposed to the cytoplasmic side, a hydrophobic transmembrane segment forming a putative $\alpha$-helix mediating anchorage in the membrane and a hydrophilic C-terminal portion exposed outside the cell. Evidence of the membrane-spanning nature of the protein has also been obtained in solubility studies in which the IMP of the AP agent was recovered in the Triton-X114 phase but not in the aqueous phase. As such proteins are anchored by hydrophobic interactions and other forces, they cannot be dissolved in low-ionicstrength buffers but require the use of a suitable surfactant (Wieslander et al., 1992).

The IMP of the AP phytoplasma showed similarities to an antigenic membrane protein of the SPWB agent described by Yu et al. (1998). Not only was there a significant sequence homology at both DNA and protein level, the SPWB phytoplasma protein is also similar in size (172 amino acids versus 165 residues of AP agent) and shows the same structural characteristics of a putative transmembrane protein with an $\mathrm{N}$ terminus in/C terminus out topology. In addition, the SPWB membrane protein gene seems to be similarly organized on the phytoplasma chromosome in that it is preceded by an ORF encoding a protein that shows $40.7 \%$ sequence similarity to protein $\mathrm{P}-318 \mathrm{~A}$ of the AP phytoplasma, identified in our work at the same position, i.e. upstream of the IMP gene. Yu et al. (1998) detected an antigenic membrane protein gene similar to that identified in the SPWB agent in the phylogenetically closely related peanut witches' broom pathogen but not in other phytoplasmas tested. Similarly, the genes encoding proteins $\mathrm{P}-318 \mathrm{~A}$ and $\mathrm{P}-318 \mathrm{~B}$ of the AP phytoplasma hybridized in our Southern blot studies with DNA from the closely related PD and ESFY phytoplasmas. However, the AP phytoplasma gene probes did not hybridize to DNA from AY and stolbur phytoplasma strains, which is consistent with the lack of taxonomic similarity between the AP phytoplasma and these two strains (Seemüller et al., 1998). There was also no significant sequence similarity between the gene and gene product of the AP phytoplasma IMP and a major IMP of the 'chlorante' strain of the AY group. However, the predicted properties of this protein seem to be different, with a clear $\mathrm{C}$ terminus in/ $\mathrm{N}$ terminus out putative topology (Barbara et al., 1998).

The IMP gene of the AP phytoplasma was expressed in E. coli. The pAbs prepared to the expression product reacted specifically with its homologous antigen and a similar sized antigen in preparations from AP-diseased plants. They proved suitable for the detection of the AP phytoplasma in infected plants by ELISA. In other work, the pAbs to the expression product showed a considerably higher specific titre and a lower background reaction than existing antibodies to the AP phytoplasma, raised to antigen preparations from infected plants $(M$. Berg \& E. Seemüller, unpublished results). The heterologous expression of a phytoplasma protein on a preparative scale and the use of an expressed phytoplasma protein for antibody production have not been reported previously. Numerous antisera raised to protein preparations from infected plant tissue have been produced for about 20 years (Sinha, 1979; Lee \& Davis, 1992). However, despite tedious purification procedures, plant-derived immunogens are contaminated with plant components, resulting in antisera that often have relatively low specific titres and react with antigens from healthy plants. Although phytoplasmas purified from insects may give lower background reactions with plant antigens, insect-derived immunogens are often not available. The problem of specificity associated with the use of antigen preparations from infected tissue can be overcome by the use of mAbs. However, production of $\mathrm{mAbs}$ is also difficult and $\mathrm{mAbs}$ may be too specific for practical phytoplasma detection (Lin \& Chen, 1985). Therefore, our approach to raise antibodies to a bacterially expressed phytoplasma protein seems to offer a promising alternative to the development of antibodies to antigen preparations from infected plants and insect vectors for phytoplasma detection and characterization.

\section{ACKNOWLEDGEMENTS}

We thank R. Loewe and C. Stahl for performing ELISA tests. We are grateful to W. Jelkman and A. Kollar for valuable discussions on gene expression and protein purification. The work was supported by a grant from the European Commission (CIPA-CT94-0128) to E.S. 


\section{REFERENCES}

Ahrens, U. \& Seemüller, E. (1992). Detection of DNA of plant pathogenic mycoplasmalike organisms by a polymerase chain reaction that amplifies a sequence of the $16 \mathrm{~S}$ rRNA gene. Phytopathology 82, 828-832.

Barbara, D. J., Davies, D. L. \& Clark, M. F. (1998). Cloning and sequencing of a major membrane protein from chlorante (aster yellows) phytoplasma. Proceedings of the $12 \mathrm{th}$ International Meeting of the International Organization of Mycoplasmology, Sydney, Australia, p. 183. Sydney: International Organization of Mycoplasmology.

Berg, M. \& Seemüller, E. (1999). Chromosomal organization and nucleotide sequence of the genes coding for the elongation factors $\mathrm{G}$ and $\mathrm{Tu}$ of the apple proliferation phytoplasma. Gene 226, 103-109.

Bordier, C. (1981). Phase separation of integral membrane proteins in Triton X-114 solution. J Biol Chem 256, 1604-1607.

Chang, F. L., Chen, C. C. \& Lin, C. P. (1995). Monoclonal antibody for the detection and identification of a phytoplasma associated with rice yellow dwarf. Eur J Plant Pathol 101, 511-518.

Clark, M. F., Morton, A. \& Buss, S. L. (1989). Preparation of mycoplasma immunogens from plants and a comparison of polyclonal and monoclonal antibodies made against primula yellows MLO-associated antigens. Ann Appl Biol 114, 111-124.

Errampalli, D. \& Fletcher, J. (1993). Production of monospecific polyclonal antibodies against aster yellows mycoplasmalike organism-associated antigen. Phytopathology 83, 1279-1282.

Garnier, M., Zreik, L. \& Bove, J. M. (1991). Witches' broom, a lethal mycoplasmal disease of lime trees in the Sultanate of Oman and the United Arab Emirates. Plant Dis 75, 546-551.

Hoheisel, J. D., Lennon, G. G., Zehetner, G. \& Lehrach, H. (1991). Use of high coverage reference libraries of Drosophila melanogaster for rational data analysis: a step towards mapping and sequencing of the genome. J Mol Biol 220, 903-914.

Holton, T. A. \& Graham, M. W. (1990). A simple and efficient method for direct cloning of PCR products using ddT-tailed vectors. Nucleic Acids Res 19, 1156.

Jiang, Y. P., Lei, J. D. \& Chen, T. A. (1988). Purification of aster yellows agent from diseased lettuce using affinity chromatography. Phytopathology 78, 828-831.

Kahane, I. \& Horowitz, S. (1993). Adherence of mycoplasmas to cell surface. In Subcellular Biochemistry, vol. 20, pp. 225-241. Edited by S. Rottem \& I. Kahane. New York \& London: Plenum.

Kollar, A. \& Seemuller, E. (1989). Base composition of the DNA of mycoplasmalike organisms associated with various plant diseases. J Phytopathol 127, 177-186.

Krause, D. C. \& Taylor-Robinson, D. (1992). Mycoplasmas which infect humans. In Mycoplasmas. Molecular Biology and Pathogenesis, pp. 414-444. Edited by J. Maniloff, R. N. McElhaney, L. R. Finch \& J. B. Baseman. Washington, DC: American Society for Microbiology.

Laemmli, U. K. (1970). Cleavage of structural proteins during the assembly of the head of bacteriophage T4. Nature 136, 180-184.

Lee, I.-M. \& Davis, R. E. (1992). Mycoplasmas which infect plants and insects. In Mycoplasmas. Molecular Biology and Pathogenesis, pp. 379-390. Edited by J. Maniloff, R. N. McElhaney,
L. R. Finch \& J. B. Baseman. Washington, DC: American Society for Microbiology.

Lin, C.-P. \& Chen, T. A. (1985). Monoclonal antibodies against the aster yellows agent. Science 227, 1233-1235.

Lorenz, K.-H., Schneider, B., Ahrens, U. \& Seemüller, E. (1995). Detection of the apple proliferation and pear decline phytoplasmas by PCR amplification of ribosomal and nonribosomal DNA. Phytopathology 85, 771-776.

McCoy, R. E., Caudwell, A., Chang, C. J. \& 16 other authors (1989). Plant diseases associated with mycoplasma-like organisms. In The Mycoplasmas, vol. V, pp. 546-623. Fdited by R. F. Whitcomb \& J. G. Tully. San Diego: Academic Press.

Milne, R. G., Ramasso, E., Lenzi, R., Masenga, V., Sarindu, S. \& Clark, M. F. (1995). Pre- and post-embedding immunogold labeling and electron microscopy in plant host tissue of three antigenically unrelated MLOs: primula ycllows, tomato big bud and Bermuda grass white leaf. Eur J Plant Pathol 101, 57-67.

Onuki, M., Hayashi, T. \& Sakai, J. (1992). Detection of antigenic proteins of mycoplasmalike organism (MLO) associated with rice yellow dwarf from infected rice plants. Ann Phytopathol Soc Jpn 58,613 .

Saeed, E., Rage, P. \& Cousin, M. T. (1992). Determination of the antigenic protein size associated with faba bean phyllody ML(O) by using (SDS-PAGE) electrophoresis and immunotransfer. I Phytopathol 136, 1-8.

Sambrook, J., Fritsch, E. F. \& Maniatis, T. (1989). Molecular Cloning: a Laboratory Manual, 2nd edn. Cold Spring Harbor, NY : Cold Spring Harbor Laboratory.

Seddas, A., Meignoz, R., Daire, X., Boudon-Padieu, E. \& Caudwell, A. (1993). Purification of grapevine flavescence doree MLO (mycoplasma-like organism) using immunoaffinity. (urr Microbiol 27, 229-236.

Seemüller, E., Marcone, C., Lauer, U., Ragozzino, A. \& Göschl, M. (1998). Current status of molecular classification of the phytoplasmas. J Plant Pathol 80, 3-26.

Shine, J. \& Dalgarno, L. (1974). The $3^{\prime}$-terminal sequence of Escherichia coli $16 \mathrm{~S}$ ribosomal RNA : complementarity to nonsense triplets and ribosome binding sites. Proc Natl Acad Sci USA 71, 1342-1346.

Sinha, R. C. (1979). Purification and serology of mycoplasma-like organisms from aster yellows-infected plants. Can I Plant Pathol $1,65-70$.

Wieslander, A., Boyer, M. J. \& Wroblewski, H. (1992). Membrane protein structure. In Mycoplasmas. Molecular Biology and Pathogenesis, pp. 93-112. Edited by J. Maniloff, R. N. McElhaney, L. R. Finch \& J. B. Baseman. Washington, DC: American Society for Microbiology.

Wise, K. S., Yogev, D. \& Rosengarten, R. (1992). Antigenic variation. In Mycoplasmas. Molecular Biology and Pathogenesis, pp. 473-489. Edited by J. Maniloff, R. N. McElhaney, L. R. Finch \& J. B. Baseman. Washington, DC: American Society for Microbiology.

Yu, Y.-L., Yeh, K.-W. \& Lin, C.-P. (1998). An antigenic protein gene of a phytoplasma associated with sweet potato witches' broom. Microbiology 144, 1257-1262.

Received 6 January 1999; revised 22 April 1999; accepted 6 May 1999 